\title{
BIOLOGICAL AND GENETIC CHARACTERISTICS OF UROPATHOGENIC Escherichia coli STRAINS
}

\author{
Wanderley Dias da SILVEIRA(1), Fabiane BENETTI(1), Marcelo LANCELLOTTI(1), Alessandra FERREIRA(1), Vera Nisaka SOLFERINI(2) \& Marcelo BROCCHI(3)
}

\begin{abstract}
SUMMARY
The aim of the present study was to determine biological characteristics such as expression of fimbriae, Congo red binding, production of hemolysin and aerobactin, adhesion to HeLa and uroepithelial cells and invasion of HeLa cells by Escherichia coli isolates obtained from patients showing clinical signs of urinary tract infection (UTI). Also, the presence of genes (apa, afa, spa) for fimbria expression and cytotoxic necrotizing factors (CNF1, CNF2) was assayed using specific primers in PCR. The data obtained were compared with the clonal relationships obtained by analysis of multilocus enzyme electrophoresis (MLEE), restriction fragment length polymorphism (RFLP) of the rDNA (ribotyping) and enterobacterial repetitive intergenic consensus-PCR (ERIC-PCR). All isolates but one presented a combination of at least two of the characteristics studied, a fact suggesting the presence of pathogenicity islands (PAIs). Diffuse adherence type to HeLa cells was observed to occur in most of the strains, but adhesion to uroepithelial cells seems to be a more reliable test to verify pathogenicity. Although four strains seemed to be able to invade HeLa cells when assayed by light microscopy, electron microscopy studies demonstrated that these strains were not invasive. MLEE, RFLP and ERIC-PCR were able to group the isolates differently into main clusters that were not correlated with the presence of pathogenic traits.
\end{abstract}

KEYWORDS: Escherichia coli; Clonal relationship; Urinary infection; Virulence traits; Genetic analysis.

\section{INTRODUCTION}

Escherichia coli is one of the major causes of human infectious diseases and is by far the most common cause of urinary tract infection (UTI). The biological characteristics of uropathogenic E. coli strains (UPEC) include hemolysin and aerobactin production, expression of $\mathrm{P}$ fimbriae, serum resistance, cytotoxic necrotizing factor (CNF), and capsule production. These strains belong to a small number of $\mathrm{O}$ serogroups ${ }^{10,13,14,17,24,25,27,32,40}$. The genes responsible for expression of these characteristics are normally clustered in DNA regions denominated pathogenic islands (PAIs) $)^{9,20,37}$.

Biochemical and molecular techniques such as multilocus enzyme electrophoresis (MLEE), restriction fragment length polymorphism (RFLP) of rDNA (ribotyping) and DNA profile obtained after the polymerase chain reaction with ERIC primers specific for enterobacterial repetitive intergenic consensus (ERIC-PCR) have been used to identify and characterize distinct bacterial populations and to study the clonal relationships among subgroups inside these populations $\mathbf{s}^{1,23,28,30,38,41,47,48,49}$.

In the present study we analyzed urinary tract $E$. coli isolates to obtain possible evidence of a correlation between biological characteristics that could represent pathogenicity traits of these strains and the clonal relationships as assayed by MLE, RFLP of rDNA (ribotyping) and ERIC-PCR.

\section{MATERIAL AND METHODS}

Bacterial strains and media: Thirteen wild-type uropathogenic $E$. coli strains were isolated from patients with urinary tract infection (UTI) at the School of Medicine of the University of Campinas, (UNICAMP), Campinas, Brazil. CFA ${ }^{15}$, LB and LA media ${ }^{39}$ were used routinely for bacterial growth. All strains were stored at $-70{ }^{\circ} \mathrm{C}$ in $\mathrm{LB}$ medium plus $15 \%$ glycerol to avoid plasmid losses. Strain ORN115 ${ }^{33}$ was used as a standard for expression of type 1 fimbriae. Strain LG1522 was used for production of aerobactin.

Hemagglutination and expression of type 1 and $P$ fimbriae: The expression of type 1 fimbriae, or D-mannose-resistant fimbria types by the bacterial strains was determined by agglutinating human and guinea pig red blood cells in the presence or in the absence of D-mannose, as described by EVANS et al. ${ }^{16}$. Type $\mathrm{P}$ fimbria expression was determined using a commercial P-fimbria-specific agglutination test as described by BLANCO et al. ${ }^{4}$.

Hemolysin production: Production of hemolysin was assayed by growing the different strains in LB medium overnight $\left(37^{\circ} \mathrm{C}\right)$ and dropping $50 \mu \mathrm{L}$ of this culture on a Petri dish containing sheep blood agar. The culture was incubated at $37{ }^{\circ} \mathrm{C}$ overnight and hemolysin production was verified by the presence of a clear hemolytic halo around the colony.

(1) Departamento de Microbiologia e Imunologia, Instituto de Biologia, Universidade Estadual de Campinas, UNICAMP, CP 6109, 13081-970 Campinas, SP, Brasil.

(2) Departamento de Genética e Evolução, Instituto de Biologia, Universidade Estadual de Campinas, UNICAMP, CP 6109, 13081-970 Campinas, SP, Brasil.

(3) Departamento de Biologia Celular e Molecular e Bioagentes Patogênicos, Faculdade de Medicina de Ribeirão Preto, USP, Ribeirão Preto, SP, Brasil.

Correspondence to: Wanderley Dias da Silveira; Tel.: (0xx19) 3788 6268; e-mail: wds@ obelix.unicamp.br 
Detection of cytotoxic necrotizing factors (CNF) by PCR: Primers CNFA (5'CTGGACTCGAGGTGGTGG3') and CNFB (5'CTGCTG TCAACCACAGCC3') were first used to detect the CNF1 or CNF2 genes, primers CNF1-A (5'GAACTTATTAAGGATAGT3') and CNF1-B (5'CATTATTTATAACGCTG3') were used to detect CNF1, and primers CNF2-A (5'AATCTAATTAAAGAGAAC3') and CNF2-B (5'CATGC TTTGTATATCTA3') were used to detect CNF2. PCR was carried out as described by BLANCO et al. ${ }^{8}$.

Aerobactin production: Production of aerobactin by the isolated strains was assayed by growing strains in LB medium containing 200 $\mu \mathrm{M}$ of $\alpha$ - $\alpha$-dipyridyl at $37^{\circ} \mathrm{C}$ for $24 \mathrm{~h}$ without shaking. The growth was spun for $3 \mathrm{~min}(12,000 \mathrm{~g})$, the supernatants were filtered through a nitrocellulose membrane $(0.22 \mu \mathrm{m})$ and aliquots of $50 \mu \mathrm{L}$ were added to orifices made in LA medium previously seeded with strain LG $1522^{11}$. The Petri dishes were kept at $37{ }^{\circ} \mathrm{C}$ for $48 \mathrm{~h}$ and the production of aerobactin was visualized by the growth of strain LG 1522 around the orifices.

Congo red binding: Congo red binding was assayed as described by BERKHOFF \& VINAL ${ }^{3}$. Briefly, strains were grown in LB medium $\left(37{ }^{\circ} \mathrm{C}, 24 \mathrm{~h}\right)$ and seeded onto CR agar (trypticase soy agar supplemented with $0.03 \%$ Congo red dye and $0.15 \%$ bile salts) and the cultures were incubated for $24 \mathrm{~h}\left(37^{\circ} \mathrm{C}\right)$. Congo-red-positive E. coli isolates were identified by the appearance of red colonies.

Adherence to uroepithelial cells: The adherence capacity of the different bacterial isolates to uroepithelial cells was assayed as described by SVANBORG-EDEN ${ }^{44}$ and SVANBORG-EDEN et al. ${ }^{45}$. Briefly, squamous and transitional epithelial cells from the urine sediment of one human female donor without a known previous history of urinary tract infection were suspended in PBS. Bacteria $\left(10^{8}\right.$ cells $)$ were added to $10^{5}$ epithelial cells in PBS with D-mannose diluted to a final concentration of $0.5 \%$ in a volume of $1.0 \mathrm{~mL}$. After incubation for 60 min at $37^{\circ} \mathrm{C}$, unattached bacteria were eliminated by repeated washing with PBS and the cells fixed and Gram stained. The number of bacteria attached was counted by directed light microscopy. Adherence was defined as the mean number of bacteria attached to 40 epithelial cells. Strain ORN 115 was used as the type 1 fimbria positive control.

HeLa cell adherence and invasion assays: The adherence of the different isolates to HeLa cells was determined as described by CRAVIOTO et al. ${ }^{12}$, with infection periods of 3 and $6 \mathrm{~h}$. Strains that produced cell lysis within these periods were assayed by adherence for periods of 10 minutes to 3 hours separated by 10 minute intervals. Invasion assay was performed by observation of internalized bacterial cells by light microscopy and confirmed by electron microscopy as described by JOUVE et $a l .^{26}$.

Detection of pap, $\boldsymbol{s} \boldsymbol{f} \boldsymbol{a}$ and $\boldsymbol{a} \boldsymbol{f} \boldsymbol{a}$ sequences by PCR: Primers pap1 (5'GACGGCTGTACTGCAGGGTGTGGCG3'), pap2 (5'ATATC CTTTCTGCAGGGATGCAATA3'), sfa1(5'CTCCGGAGAACTGGG TGCATCTTAC 3'), sfa2(5'CGGAGGAGTAATTACAAACCTG GCA3'), afa1(5'GCTGGGCAGCAAACTGATAACTCTC 3'), and afa 2 (5'CATCAAGCTGTTTGTTCGTCCGCCG 3') described by BLANCO et al. ${ }^{7}$ were used to detect the pap, sfa and afa sequences, respectively, under the conditions described by the authors.
Preparation of enzyme extracts and electrophoretic enzyme typing: Escherichia coli isolates were grown overnight at $37^{\circ} \mathrm{C}$ in 50 $\mathrm{ml}$ of LB medium and pelleted by centrifugation $(8,000 \mathrm{~g}-2 \mathrm{~min})$ at 4 ${ }^{\circ} \mathrm{C}$. The sediment obtained was suspended in $2 \mathrm{~mL}$ of $10 \mathrm{mM}$ Tris- $1 \mathrm{mM}$ EDTA-0.5 mM NADP, pH 6.8, and the cells were lysed with a Brownsonic sonicator with three sonication pulses of 20 seconds, each followed by at least $1 \mathrm{~min}$ of ice bath cooling. Each sample was centrifuged in a $1.5 \mathrm{ml}$ microcentrifuge tube for $20 \mathrm{~min}$ at $12000 \mathrm{~g}\left(4^{\circ} \mathrm{C}\right)$. The supernatant was filtered through $0.2 \mu \mathrm{m}$ pore sterile filters and $200 \mu \mathrm{l}$ aliquots were stored frozen. Electrophoretic analysis of enzymes and subsequent staining procedures were performed as described by SELANDER et $a l{ }^{41}$. The following enzymes were assayed: adenylate kinase (ADK; EC 2.7.4.3), isocitrate dehydrogenase (IDH; EC 1.1.1.42), alpha esterase (EST; EC 3.1.1.1), phosphoglucose isomerase (PGI; EC 5.3.1.9), hexokinase (HEX; EC 2.7.1.1), malate dehydrogenase (MDH; EC 1.1.1.37), and glucose-6-phosphate dehydrogenase (G6PDH; EC 1.1.1.49).

Ribotyping (RT) analyses: Genomic bacterial DNA was extracted as described by VAN SOOLINGEN et al. ${ }^{46}$ and resuspended in TE buffer plus $10 \mathrm{mg} / \mathrm{mL}$ RNAse. DNA (4 $\mu \mathrm{g})$ was digested with $50 \mathrm{U}$ of EcoRI or HindIII as specified by the manufacturer (Life Technologies) and analyzed by electrophoresis using $0.7 \%$ submersed agarose gels in TE buffer as described by SAMBROOK et al. ${ }^{39}$. One Kb DNA standard (Life Technologies) was used as migration reference in each gel. Sizeseparated restriction fragments were transferred to a $0.45 \mu \mathrm{m}$ nitrocellulose membrane (Pharmacia) which was processed for southern blotting as described by SAMBROOK et al. ${ }^{39}$. The SalI fragment of plasmid pUC 18 containing Streptomyces (lividans) violaceoruber TK21 $r r n B^{51}$ was used as a probe. The probe was randomly labeled with $[\alpha-$ $\left.{ }^{32} \mathrm{P}\right] \mathrm{dCTP}$. Hybridization was performed at $45{ }^{\circ} \mathrm{C}$ (high stringency) as recommended by SAMBROOK et al. ${ }^{39}$.

ERIC-PCR analysis: Genomic bacterial DNA was extracted as described for ribotyping analysis. DNA $(2 \mu \mathrm{L})$ was amplified by PCR (30 cycles of 30 seconds at $90^{\circ} \mathrm{C}, 1 \mathrm{~min}$ at $52^{\circ} \mathrm{C}, 8 \mathrm{~min}$ at $72^{\circ} \mathrm{C}$ followed by a final extension cycle of $16 \mathrm{~min}$ at $72^{\circ} \mathrm{C}$ ) using the sequences ERIC 1 (5'ATGTAAGCTCCTGGGGATTCAC3') and ERIC 2 (5'AAGTAA GTGACTGGGCTGAGCG3') as specific primers for the enterobacterial repetitive intergenic consensus ${ }^{47}$. DNA $(10 \mu \mathrm{L})$ from each reaction was run on $1.2 \%$ submersed agarose gel. The DNA profiles were recorded using black and white films after ethidium bromide staining of the gel. Each reaction was performed twice to ensure the accuracy of the reaction and reactions yielding different results were double-run again.

Data analysis: Isoenzymes obtained by multilocus enzyme electrophoresis and rDNA and ERIC-PCR patterns were recorded and the presence of a band was coded as 1 and the absence of a band as 0 in a data matrix and analyzed by the POPGENE software, version $1.31^{50}$. Dendrograms of dissimilarity were constructed for each case.

\section{RESULTS}

Several biological characteristics of 13 Escherichia coli strains isolated from patients showing clinical signs of urinary tract infection were studied. These biological characteristics (Table 1) included in vitro absorption of Congo red dye, expression of type 1 and type $\mathrm{P}$ fimbriae; search for pap, sfa, afa and cnf genes by PCR amplification using specific 
Table 1

Uropathogenic strains and biological characteristics studied

\begin{tabular}{|c|c|c|c|c|c|c|c|c|c|c|c|}
\hline \multirow[t]{2}{*}{ Strains } & \multicolumn{2}{|c|}{$\begin{array}{c}\text { Adhesion } \\
\text { HeLa }\end{array}$} & \multirow[b]{2}{*}{ Uro } & \multirow[b]{2}{*}{ Cyt } & \multirow[b]{2}{*}{ Hemo } & \multirow[b]{2}{*}{$\mathbf{A E}$} & \multirow[b]{2}{*}{ CRB } & \multicolumn{4}{|c|}{ Fimbr. Expr. } \\
\hline & WM & $\mathbf{M}$ & & & & & & INV & Type1 & $\mathbf{P}$ & PCR amp. \\
\hline 01 & $\mathrm{DA}$ & DA & 13 & - & + & - & + & - & + & + & pap, sfa \\
\hline 02 & DA & DA & 16 & - & - & + & + & - & - & + & pap \\
\hline 03 & DA & DA & 62 & - & + & - & + & - & + & + & pap, sfa, afa \\
\hline 04 & - & - & 19 & - & - & + & + & + & - & + & pap, afa \\
\hline 05 & DA & DA & 25 & - & + & - & + & - & + & - & pap \\
\hline 06 & - & - & 20 & - & - & - & - & - & - & + & pap \\
\hline 07 & DA & - & 8 & - & + & - & + & - & + & - & sfa, cnf1 \\
\hline 08 & EA & EA & 45 & + & + & - & + & - & + & - & pap, sfa, cnf 1 \\
\hline 09 & DA & DA & 18 & - & - & - & + & - & + & + & pap \\
\hline 10 & DA & DA & 17 & - & + & + & + & + & + & ND & sfa \\
\hline 11 & - & - & 08 & - & + & - & + & + & + & - & sfa \\
\hline 12 & LA & LA & 15 & - & - & - & + & - & + & - & pap \\
\hline 13 & DA & DA & 63 & + & + & + & + & + & - & - & pap, afa \\
\hline
\end{tabular}

Uro $=$ adhesion to uroepithelial cells (mean observed in 40 cells); Adhesion to HeLa cells: $\mathrm{M}=$ with mannose; $\mathrm{WM}=$ without mannose; Cyt $=$ cytotoxin production; Hemo = hemolysin production; $\mathrm{AE}=$ aerobactin expression; $\mathrm{CRB}=$ Congo red binding; $\mathrm{INV}=$ invasion of HeLa cells; Fimbr. Expr. = fimbrial expression; DA = diffuse adherence; $\mathrm{LA}=$ localized adherence; $\mathrm{EA}=$ enteroaggregative adherence; $\mathrm{ND}=$ not determined.

primers; production of hemolysin and aerobactin; capacity of adherence to uroepithelial cells and adherence to and invasion of HeLa cells cultured in vitro (Fig. 1) in the presence and absence of the sugar D-mannose. These same strains were also compared by gel electrophoresis of isozymes (ADK, IDH, $\alpha$-EST, PGI, HEX, MDH, G6PDH), restriction fragment length polymorphism (RFLP) of ribosomal DNA, and ERIC-PCR (Fig. 2-7).

The results showed that most of the strains $(92.3 \%)$ were able to absorb Congo red dye. Eight (61.53\%) strains, when grown on blood agar medium, produced hemolysin.

Of four aerobactin-producing isolates (30.7\%), two were able to express hemolysin and had the ability of absorbing Congo red dye. The other two aerobactin-producing isolates were able to bind Congo red dye but did not produce hemolysin.

Bacterial adherence to and colonization of the urinary tract by uropathogenic $E$. coli strains are mediated by the expression of several types of fimbrial and nonfrimbrial adhesins ${ }^{19,21,22,24,52}$. Under our experimental conditions, when using anti-P fimbria serum and red blood cell agglutination, nine strains $(69.2 \%)$ were able to express type 1 fimbriae. Three $(23 \%)$ of these $(01,03,09)$ also expressed type $\mathrm{P}$ fimbriae and another three $(02,04,06)$ expressed type P but not type 1 fimbriae. Amplification by PCR using specific primers for the pap, sfa and afa genes indicated that strains 02, 05, 06, 09 and 12 had pap-related sequences only $(38.46 \%)$ and strains 10 and 11 had $s f a$-related sequences only (15.38\%); strain 01 had the pap and sfa genes (7.69\%); strains 04 and 13 had the pap and afa genes (15.38\%), and strain 03 had the pap, sfa and $a f a$ genes $(7.69 \%)$.

The PCR amplification tests for detection of $c n f$-related sequences also demonstrated that two strains $(07,08)$ had CNF1-related DNA sequences. CNF2 related sequences were not found in any of the strains studied.

The adherence and invasion tests carried out in the present study with HeLa cells (Fig. 1) demonstrated that three isolates $(04,06,11)$ were unable to adhere (Fig. 1b), one (12) showed localized adherence (Fig. 1d), one (08) presented enteroaggregative adherence (Fig. 1e), and eight $(61.53 \%)$ showed diffuse adherence (Fig. 1c) similar to that described by GERMANI et al. ${ }^{18}$ also in uropathogenic E. coli strains. Although afarelated sequences were present in three of these strains $(03,04,13)$, and four $(04,10,11,13)$ seemed to be able to invade this cell type as assayed by light microscopy (Fig. 1f), the invasion capacity was not confirmed by electron microscopy, indicating that these strains are noninvasive.

Strains 08 and 13 when tested for adhesion capacity showed cytotoxic activity, which was higher in strain 08. The adhesion analysis of these strains was possible because they exhibited adhesion capacity over periods of time (10 and 20 minutes) shorter than those used as standards and prior to the appearance of the cytotoxic effect.

Adherence of E. coli isolates to uroepithelial cells is used to differentiate between uropathogenic and fecal strains ${ }^{44,45}$. These authors suggest that uropathogenic strains may present a mean of 20 bacteria/ cell or more, while fecal strains may present a mean of about 7 bacteria/ cell. Our adherence assays (HeLa and uroepithelial cells) showed that $76.9 \%$ of the isolates presented adherence to HeLa cells and the mean number of bacteria adhered to uroepithelial cells ranged from 8 to 63 . Isolates 04 and 06, that were negative for adherence to HeLa cells, showed a mean number of bacteria/cells very close to that needed for a strain to be considered uropathogenic. Both of them produced $\mathrm{P}$ fimbriae but isolate 06 had no capacity for expression of any other biological characteristic, while strain 04 produced aerobactin and absorption of Congo red dye. On the other hand, isolates 07 (DA with D-mannose) 


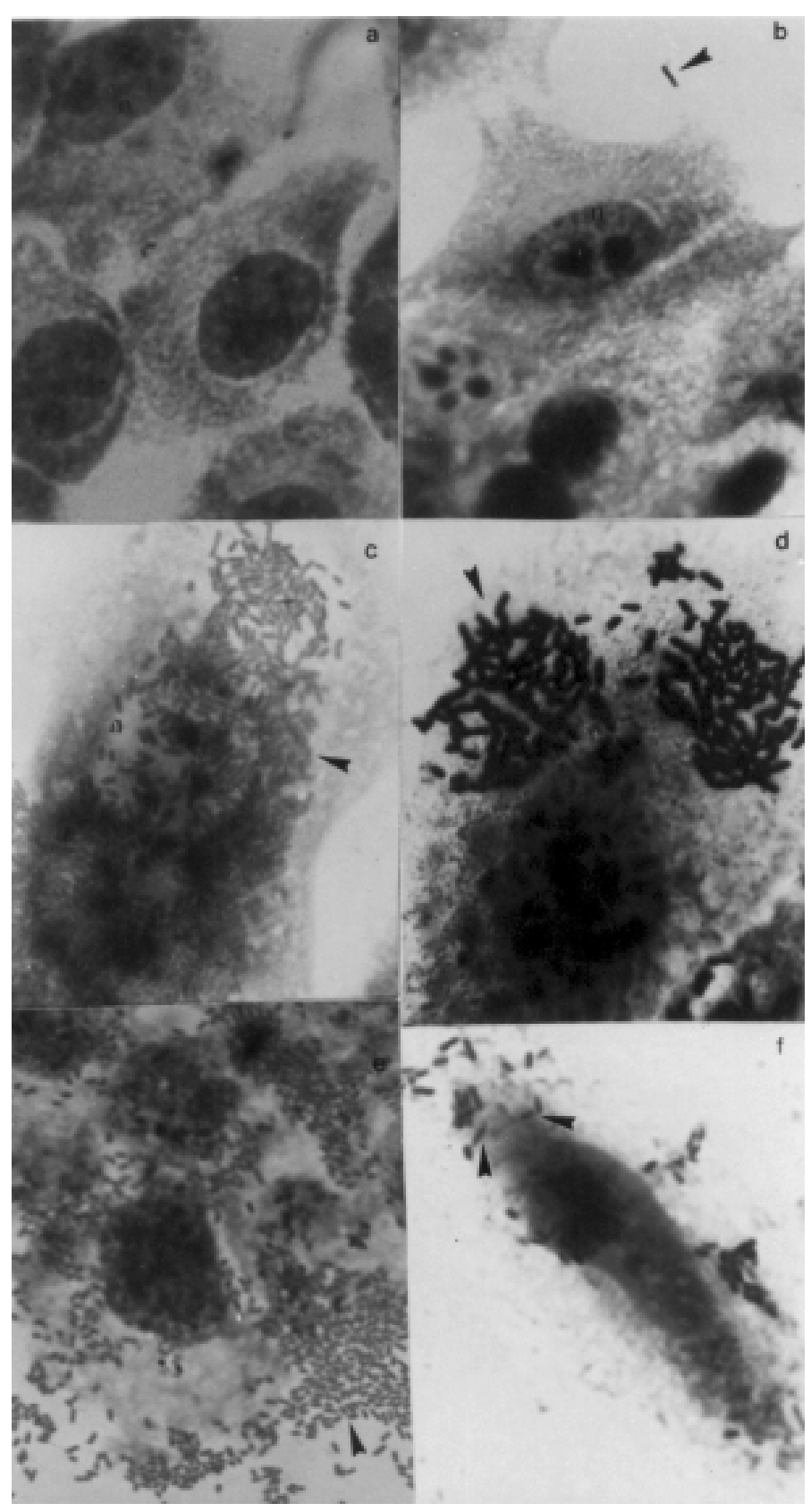

Fig. 1 - Patterns of adherence to HeLa cells shown by urinary Escherichia coli isolates: (a) HeLa cells cultivated in the absence of bacterial cells; (b) Arrows point to negative adhesion bacteria; (c) diffuse adherence; (d) localized adherence; (e) enteroaggregative adherence; (f) invasion-positive bacteria. Magnification, 1000X.

and 11 (adhesion negative) presented a low mean frequency of bacterial cell adherence to uroepithelial cells. These same isolates showed biological characteristics normally considered to be pathogenic traits and produced type 1 fimbriae, but not type $\mathrm{P}$ fimbriae. All three isolates $(03,08,13)$ showing the highest adherence to uroepithelial cells had diffuse adhesion and expressed hemolysin and absorption of Congo red dye. Isolate 13 did not express type $\mathrm{P}$ fimbriae but expressed aerobactin.

\begin{tabular}{|c|c|c|c|c|c|c|c|c|c|c|c|c|c|}
\hline Loci & \multicolumn{13}{|c|}{ Strains } \\
\hline \multicolumn{14}{|l|}{$\overline{\text { IDH }}$} \\
\hline & - & - & - & & - & - & - & - & - & - & - & - & - \\
\hline \multicolumn{14}{|l|}{$\overline{\text { HEX }}$} \\
\hline & & & - & & & - & & - & & & - & & \\
\hline \multicolumn{14}{|c|}{$\overline{\text { G6PDH }}$} \\
\hline & & & - & & - & & & - & & & & & \\
\hline \multicolumn{14}{|l|}{ MDH } \\
\hline & - & - & - & & & & & - & - & - & - & & \\
\hline & & & & & - & & & & & & & & \\
\hline \multicolumn{14}{|l|}{$\overline{\text { EST }}$} \\
\hline & & & & - & & & & & & & - & & - \\
\hline & & & - & & - & & - & & & - & & - & \\
\hline \multicolumn{14}{|l|}{$\overline{\text { ADK }}$} \\
\hline & & & & & - & & & & & - & & & \\
\hline & - & & - & & & - & - & - & & & & & \\
\hline \multicolumn{14}{|l|}{ PGI } \\
\hline & - & - & - & - & & & & & & & - & & \\
\hline & & & & & - & - & - & - & - & - & & - & - \\
\hline
\end{tabular}

Fig. 2 - Multilocus enzyme electrophoresis (MLEE) profile of the E. coli strains studied in the present investigation. (IDH): isocitrate dehydrogenase; (HEX): hexokinase; (G6PDH): glucose-6-phosphate dehydrogenase; (MDH): Malate dehydrogenase; (EST): $\alpha$-esterase; (ADK): adenylate kinase; (PGI): phosphoglucose isomerase. Bars indicate the presence of the enzyme.

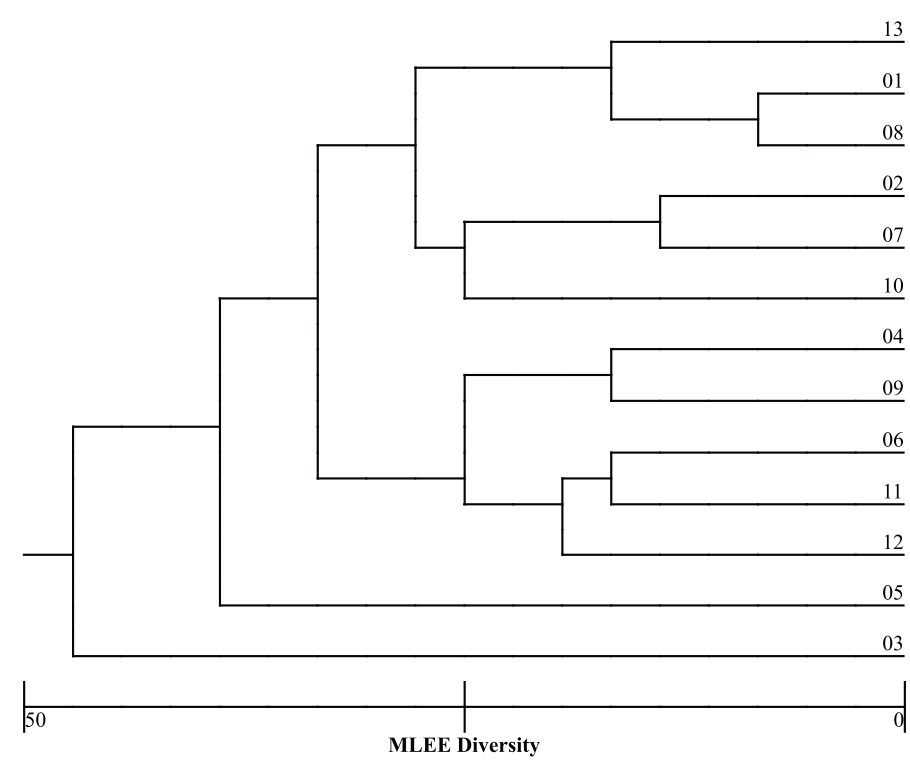

Fig. 3 - Genetic distance of urinary Escherichia coli isolates based on multilocus enzyme electrophoresis. 


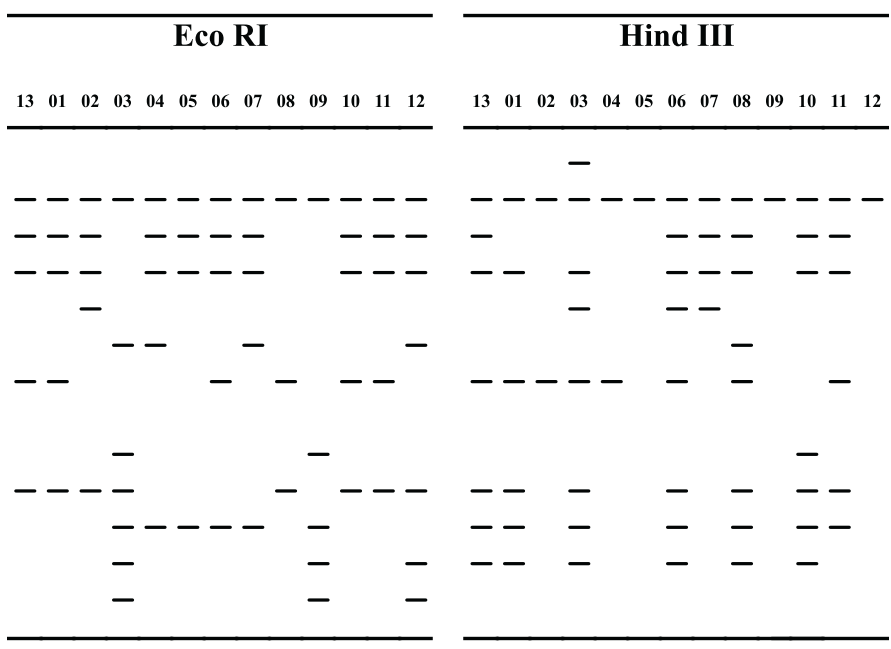

Fig. 4 - Ribotyping profiles of the urinary E. coli strains studied in the present investigation.

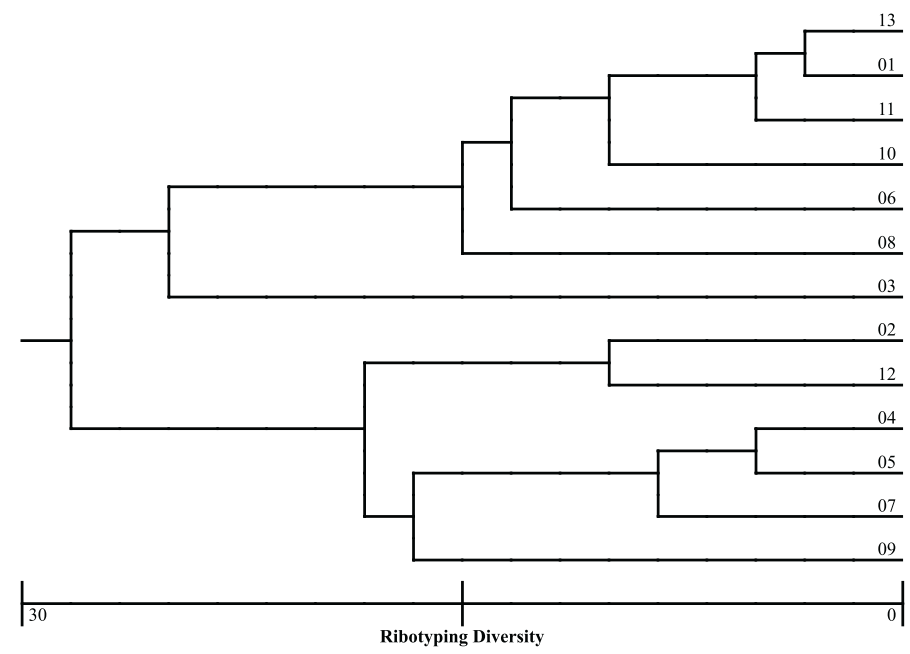

Fig. 5 - Genetic distance of urinary Escherichia coli isolates based on rybotype analyses.

Although multilocus enzyme electrophoresis, ribotyping and ERICPCR were able to discriminate between the different isolates (Fig. 2, 3, $4,5,6,7)$, separating them into pattern clusters (thirteen), the results were not the same, i.e., the genetic distances were different for each isolate depending on the method used.

\section{DISCUSSION}

The majority of the strains were able to absorb Congo red dye, a characteristic associated with pathogenicity in Shigella flexneri ${ }^{29,31}$, Yersinia pestis $^{43}$, Neisseria meningitidis, Vibrio cholerae $^{34}$, and avian septicemic Escherichia coli strains $^{3}$, suggesting that this characteristic could be used as a marker for pathogenicity in UPEC strains. To our knowledge, this is the first report on absorption of this dye by UPEC.

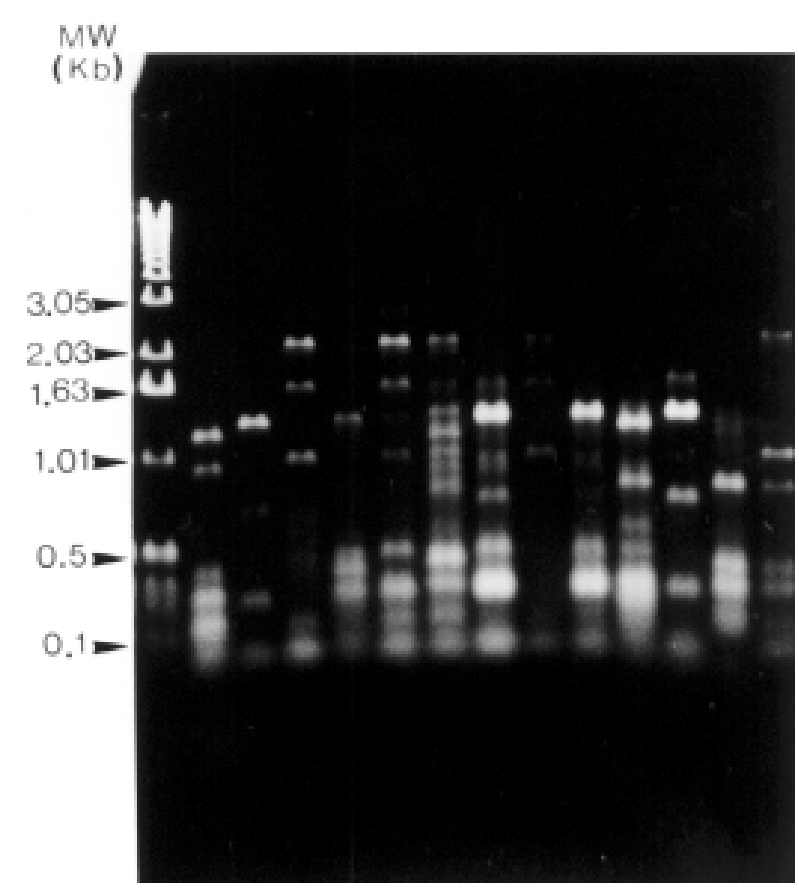

Fig. 6 - Agarose gel electrophoresis (1.2\%) of ERIC-PCR profiles of the different urinary $E$. coli strains studied in the present investigation.

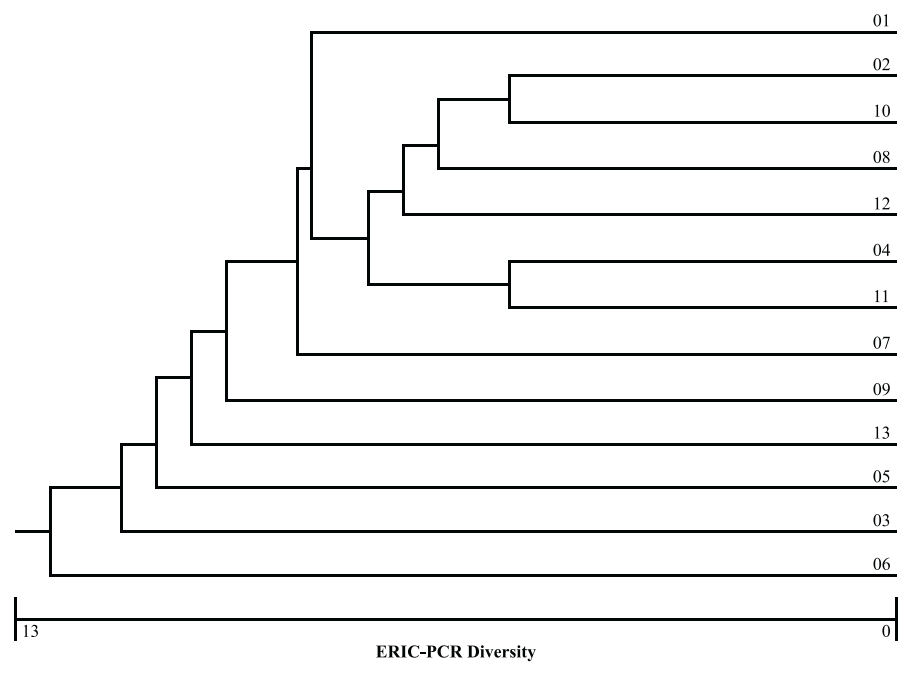

Fig. 7 - Genetic distance of urinary Escherichia coli isolates based on ERIC-PCR analysis.

A considerably high number of strains produced hemolysin, a characteristic normally described as being an important trait, although hemolysin production alone does not always equate with virulence, but may be a decisive factor in the virulence of many nephropathogenic strains, as demonstrated by BLANCO et al. ${ }^{5,6}$. ARRIAGA-ALBA et $a l .^{2}$ recently described a lower frequency of hemolysin-producing strains than that found by us. This could be explained by differences in the pathogenic status of strains because the cited studies analyzed UPEC isolated from symptomatic 
and asymptomatic infections as well. In this case, asymptomatic infections probably are caused by low pathogenic UPEC strains. Two strains were able to show cytotoxic effect in the monocell layer assay, indicating the production of a still unknown cytotoxin.

The expression of several types of fimbrial and nonfrimbrial adhesins is a common characteristic among UPEC strains ${ }^{18,20,21,23,42,49}$. A survey of the Pap, Afa and Sfa adhesins yielded results similar to those obtained by BLANCO et al. ${ }^{7}$. Only afa-related sequences were not found, indicating that this sequence alone is uncommon among uropathogenic bacterial strains. However, in contrast to the cited authors, we found three strains having $a f a$-related sequences associated either with pap or with pap and $s f a$ sequences. Our results also demonstrate a high correlation (100\%) between $\alpha$-haemolysin and one or more of the pap, $s f a$ and $a f a$ operons, a fact suggesting the presence of pathogenicity islands in these strains.

The different capacities of strains to adhere to uroepithelial cells suggest the existence of different adhesin types with different adhesion capacities. In fact we found a direct correlation between adhesion capacity and number of adhesin genes. Some discrepancies observed between adhesion assays using HeLa or uroepithelial cells led us to believe that there is no correlation between these adhesion tests. We think that although the uroepithelial cells are more difficult to obtain they will yield more reliable results concerning the pathogenicity of urinary tract infection induced by $E$. coli. For instance, SHRIKHANDE et al.$^{42}$ used this approach to characterize UPEC strains isolated in India.

One intriguing fact was that, independently of the method used to assess the clonal relationships among strains, strain 03 (pap, sfa, afa) seems to have a longer genetic distance from all the strains (MLEE) either from a group containing a larger number (ERIC-PCR) or a smaller number of strains (ribotyping). This fact led us to propose that, if pathogenicity islands are present in these strains they may have undergone an evolutionary process to adapt to their human hosts, either keeping genes and having a uropathogenic behavior or losing genes and having a non-uropathogenic behavior. This idea is supported by the fact that all the strains with only one type of operon (pap or $s f a$ ) had the smallest mean number of bacteria/uroepithelial cell and the presence of more than one fimbrial operon increased the mean number of bacteria adhered to this type of cell in two out of four strains. In this scenario, UPEC strains of low virulence are still able to cause disease in susceptible or immune-compromised hosts. Indeed, PICARD et al. ${ }^{35}$ found a direct correlation between the number of pathogenic traits exhibited by UPEC strains and virulence assayed in an animal model. These same authors and others ${ }^{36}$ also suggested that UPEC strains, despite the existence of some grade of genetic diversity, are of clonal origin.

\section{RESUMO}

\section{Características biológicas e estrutura clonal em amostras uropatogênicas de Escherichia coli}

O objetivo deste trabalho foi estudar características biológicas tais como a expressão de fímbrias e adesinas, capacidade de absorção do corante Vermelho Congo, produção de hemolisina e aerobactina, adesão e invasão a células HeLa e adesão a células do epitélio urinário em amostras de Eschericia coli isoladas de pacientes com sinais clínicos de infecção do trato urinário (UTI). A presença dos genes responsáveis pela expressão de fímbrias ( $a p a$, afa e spa) e das Citotoxinas Necrotizantes CNF1, CNF2 foi avaliada por PCR. Esses dados foram comparados com a estrutura clonal das amostras obtidas por análises de isoenzimas (MLEE), Ribotipagem (RFLP) e ERIC-PCR. Com uma única exceção, os isolados apresentaram combinação de ao menos duas das características estudadas, fato que sugere a existência de Ilhas de Patogenicidade (PAIs). A maioria das amostras apresentaram um padrão difuso de aderência a células HeLa. Os resultados indicam que a capacidade de adesão a células epiteliais do sistema urinário poderia ser um teste mais específico e correlacionado à patogenicidade. Embora os estudos com microscopia óptica indicassem que quatro linhagens pudessem ser invasivas, dados de microscopia eletrônica não confirmaram tais achados. As técnicas de MLEE, Ribotipagem e ERIC-PCR separaram os isolados em diferentes grupos principais mas estes não foram correlacionados à patogenicidade.

\section{ACKNOWLEDGMENTS}

The authors thank the Laboratório de Patologia Clínica, Faculdade de Ciências Médicas, Universidade Estadual de Campinas, for the donation of the uropathogenic E. coli strains.

This work was supported by Fundação de Amparo à Pesquisa do Estado de São Paulo-FAPESP (Grants nos. 98/03683-0, 98/4616-4 and 99/04097-0) and Conselho Nacional de Desenvolvimento Científico e Tecnológico-CNPq (Grant no. 300121/90-3).

\section{REFERENCES}

1. AMANN, R.I.; LUDWIG, W. \& SCHLEIFER, K.H. - Phylogenetic identification and in situ detection of individual microbial cells without cultivation. Microbiol. Rev., 59: 143-169, 1995.

2. ARRIAGA-ALBA, M.; RIVERA, S.R., ROMERO D.G. et al. - Frequency of colicin and hemolysins in Escherichia coli isolated from pregnant patients with urinary tract infection, symptomatic and asymptomatic. Ginec. Obstet. Méx., 68: 275-281, 2000.

3. BERKHOFF, H.A. \& VINAL, A.C. - Congo red medium to distinguish between invasive and non-invasive Escherichia coli pathogenic for poultry. Avian Dis., 30: 117-121, 1985 .

4. BLANCO, J.; ALONSO, M.P.; BLANCO, M. et al. - Establishment of three categories of P-fimbriated Escherichia coli strains that show different toxic phenotypes and belong to particular O serogroups. FEMS Microbiol. Lett., 99: 131-136, 1992a.

5. BLANCO, J.; ALONSO, M.P.; GONZÁLEZ, E.A.; BLANCO, M. \& GARABAL, J.I. Virulence factors of bacteraemic Escherichia coli with particular reference to production of cytotoxic necrotizing factor (CNF) by P-fimbriated strains. J. med. Microbiol., 31: 175-183, 1990.

6. BLANCO, J.; BLANCO, M.; ALONSO, M.P. et al. - Serogroups of Escherichia coli strains producing cytotoxic necrotizing factors CNF1 and CNF2. FEMS Microbiol. Lett., 96: 155-159, 1992b.

7. BLANCO, M.; BLANCO, J.E.; ALONSO, M.P. et al. - Detection of pap, sfa and afa adhesin-encoding operons in uropathogenic Escherichia coli strains: relationships with expression of adhesins and production of toxins. Res. Microbiol., 148: 745755, 1997.

8. BLANCO, M.; BLANCO, J.E.; BLANCO, J. et al. - Polymerase chain reaction for detection of Escherichia coli strains producing cytotoxic necrotizing factor type 1 and 2 (CNF1 and CNF2). J. microbiol. Meth., 26: 95-101, 1996. 
9. BLUM, G.; OTT, M.; LISCHEWSKI, A. et al. - Excision of large DNA regions termed pathogenicity islands from tRNA-specific loci in the chromosome of an Escherichia coli wild-type pathogen. Infect. Immun., 62: 606-614, 1994.

10. CAPRIOLI, A.; FALBO, V.; RODA, L.G.; RUGGERI, F.M. \& ZONA, C. - Partial purification and characterization of an Escherichia coli toxic factor that induces morphological cell alterations. Infect. Immun., 39: 1300-1306, 1983.

11. CARBONETTI, N.H. \& WILLIAMS, P.H. - Detection of synthesis of the hydroxamate siderophore aerobactin by pathogenic isolates of Escherichia coli. In: SUSSMAN, M. The virulence of Escherichia coli. Reviews and methods. Orlando, Academic Press, 1985. p. 419-424.

12. CRAVIOTO, A.; GROSS, R.J.; SCOTLAND, S.M. \& ROWE, B. - An adhesive factor found in strains of Escherichia coli belonging to the traditional infantile enteropathogenic serotypes. Curr. Microbiol., 3: 95-99, 1979.

13. DONNENBERG, M.S. \& WELCH, R.A. - Virulence determinants of uropathogenic Escherichia coli. In: MOBLEY, H.L.T. \& WARREN, J.W., ed. Urinary tract infections: molecular pathogenesis and clinical management. Washington, ASM Press, 1996. p. 135-174.

14. DOWLING, K.J.; ROBERTS, J.A. \& KAACK, M.B. - P-fimbriated Escherichia coli urinary tract infection: a clinical correlation. Sth. med. J. (Bgham., Ala.), 80: 1533 $1536,1987$.

15. EVANS, D.J.; EVANS, D.G. \& DUPONT, H.L. - Hemagglutination patterns of enterotoxigenic Escherichia coli determined with human, bovine, chicken and guineapig erythrocytes in the presence and absence of mannose. Infect. Immun., 23: 336346, 1979.

16. EVANS, D.J.; EVANS, D.G.; HOHNE, C. et al. - Hemolysin and K antigens in relation to serotype and hemagglutination type of Escherichia coli isolated from extraintestinal infections. J. clin. Microbiol., 13: 171-178, 1981.

17. FALBO, V.; FAMIGLIETTI, M. \& CAPRIOLI, A. - Gene block encoding production of cytotoxic necrotizing factor 1 and hemolysin in Escherichia coli isolates from extraintestinal infections. Infect. Immun., 60: 2182-2187, 1992.

18. GERMANI, Y.; BÉGAUD, E.; DUVAL, P. \& LE BOUGUÉNEC, C. - Prevalence of enteropathogenic, enteroaggregative and diffusely-adherent Escherichia coli among isolates from children with diarrhea in New Caledonia. J. infect. Dis., 174: 11241126, 1996.

19. GOLDHAR, J.; PERRY, R.; GOLEKI, J.R. et al. - Nonfimbrial mannose-resistant adhesins from uropathogenic Escherichia coli 083:K1:H4 and 014:K?:H11. Infect. Immun., 55: 1837-1842, 1987.

20. HACKER, J. - Genetic determinants coding for fimbriae and adhesins of extraintestinal Escherichia coli. Curr. Top. Microbiol. Immunol., 151: 1-27, 1990.

21. HACKER, J. - Role of fimbrial adhesins in the pathogenesis of Escherichia coli infections. Canad. J. Microbiol., 38: 720-727, 1992.

22. HALES, B.A.; BEVERLY-CLARKE, H.; HIGH, N.J. et al. - Molecular cloning and characterization of the genes for a non-fimbrial adhesin from Escherichia coli. Microb. Pathog., 5: 9-17, 1988.

23. HARAKEH, H.; BOSLEY, G.S.; KEIHLBAUCH, J.A. \& FIELDS, B.S. - Heterogeneity of rRNA gene restriction patterns of multiresistant serotype 6B Streptococcus pneumoniae strains. J. clin. Microbiol., 32: 3046-3048, 1994.

24. JOHNSON, J.R. - Virulence factors in Escherichia coli urinary tract infection. Clin Microbiol. Rev., 4: 80-128, 1991.

25. JOHNSON, J.R.; MOSELEY, S.L.; ROBERTS, P.L. \& STAMM, W.E. - Aerobactin and other virulence factor genes among strains of Escherichia coli causing urosepsis: association with patient characteristics. Infect. Immun., 56: 405-412, 1988.
26. JOUVE, M.; GARCIA, M.I.; COURCOUX, P. et al. - Adhesion to and invasion of HeLa cells by pathogenic Escherichia coli carrying the afa-3 gene cluster are mediated by the $A f a \mathrm{E}$ and $A f a \mathrm{D}$ proteins, respectively. Infect. Immun., 65: 4082-4089, 1997.

27. LATHAM, R.H. \& STAMM, W.E. - Role of fimbriated Escherichia coli in urinary tract infections in adult women: correlation with localization studies. J. infect. Dis., 149 $835-840,1984$

28. MASLOW, J.N.; WHITTAM, T.; GILKS, C. et al. - Clonal relationships among bloodstream isolates of Escherichia coli. Infect. Immun., 63: 2409-2417, 1995.

29. MAURELLI, A.T.; BLACKMON, B. \& CURTISS III, R. - Loss of pigmentation in Shigella flexneri $2 \mathrm{a}$ is correlated with loss of virulence and virulence-associated plasmid. Infect. Immun., 43: 397-401, 1984.

30. MILLEMANN, Y.; LESAGE, M.C.; CHASLUS-DANCLA, E. \& LAFONT, J.P. - Value of plasmid profiling, ribotyping, and detection of IS200 for tracing avian isolates of Salmonella typhimurium and S. enteritidis. J. clin. Microbiol., 33: 173-179, 1995.

31. OADRI, F.; HOSSAIN, S.A.; CIZNÁR, I. et al. - Congo red binding and salt aggregation as indicators of virulence in Shigella species. J. clin. Microbiol., 26: 1343-1348, 1988

32. O'HANLEY, P.; LOW, D.; ROMERO, I. et al. - Gal-gal binding and hemolysin phenotypes and genotypes associated with uropathogenic Escherichia coli. New Engl. J. Med. 313: 414-420, 1985 .

33. ONDORFF, P.E.; SPEARS, P.A.; SCHAUER, D. \& FALKOW, S. - Two models of control of pilA, the gene encoding type 1 pilin in Escherichia coli. J. Bact., 164: 321-330, 1985.

34. PAYNE, S.M. \& FINKELSTEIN, R.A. - Detection and differentiation of iron-responsive avirulent mutants on Congo red agar. Infect. Immun., 18: 94-98, 1977.

35. PICARD, B.; GARCIA, J.S.; GOURIOU, S. et al. - The link between phylogeny and virulence in Escherichia coli extraintestinal infection. Infect. Immun., 67: 546-553, 1999.

36. PRATS, G.; NAVARRO, F.; MIRELIS, B. et al. - Escherichia coli serotype O15:K52:H1 as a uropathogenic clone. J. clin. Microbiol., 38: 201-209, 2000.

37. RITTER, A.; BLUM, G.; EMÖDY, L. et al. - tRNA genes and pathogenicity islands: influence on virulence and metabolic properties of uropathogenic Escherichia coli. Molec. Microbiol., 17: 109-121, 1995.

38. RODRIGUES, J.; SCALETSKY, I.C.A.; CAMPOS, L.C. et al. - Clonal structure and virulence factors in strains of Escherichia coli of the classic serogroup O55. Infect. Immun., 64: 2680-2686, 1996.

39. SAMBROOK, J.; FRITSH, E.F. \& MANIATIS, T. - Molecular cloning: a laboratory manual. 2. ed. New York, Cold Spring Harbor Lab. Press, 1989.

40. SANDBERG, T.; KAIJSER, B.; LIDIN-JANSON, G. et al. - Virulence of Escherichia coli in relation to host factors in women with symptomatic urinary tract infection. $\mathbf{J}$. clin. Microbiol., 26: 1471-1476, 1988.

41. SELANDER, R.K.; CAUGANT, D.A.; OCHMAN, H. et al. - Methods of multilocus enzyme electrophoresis for bacterial population genetics and systematics. Appl. environ. Microbiol., 51: 873-884, 1986.

42. SHRIKHANDE, S.N.; CHANDE, C.A. \& PATHAK, A.A. - Virulence factors in uropathogenic E. coli. Indian J. Path. Microbiol., 42: 321-325, 1999.

43. SURGALLA, M.J. \& BEESLEY, E.D. - Congo red agar medium for detecting pigmentation in Pasteurella pestis. Appl. Microbiol., 18: 834-837, 1969.

44. SVANBORG-EDEN, C. - Bacterial adherence in urinary tract infections caused by Escherichia coli. Scand. J. Urol. Nephrol., 20: 81-88, 1986. 
45. SVANBORG-EDEN, C.;ANDERSSON, B.; ANIANSSON, G. et al. - Bacterial adherence in urinary and respiratory tract infection. Kansenshogaku Zasshi, 62(suppl.): 136$148,1988$.

46. VAN SOOLINGEN, D.; HERMANS, P.W.M.; HASS, P.E.W.; SOLL, D.R. \& VAN EMBDEN, J.D.A. - The occurrence and stability of insertion sequences in Mycobacterium tuberculosis complex strains; evaluation of IS-dependent DNA polymorphism as a tool in the epidemiology of tuberculosis. J. clin. Microbiol., 29: 2578-2586, 1991

47. VERSALOVIC, J.; KOEUTH, T. \& LUPSKI, J.R. - Distribution of repetitive DNA sequences in eubacteria and application to fingerprinting of bacterial genomes. Nucleic Acids Res., 19: 6823-6831, 1991.

48. WHITE, D.G.; WILSON, R.A.; SAN GABRIEL, A.; SACO, M. \& WHITTAM, T.S. Genetic relationships among strains of avian Escherichia coli associated with swollenhead syndrome. Infect. Immun., 58: 3613-3620, 1990.
49. WHITTAM, T.S. \& WILSON, R.A. - Genetic relationships among pathogenic strains of avian Escherichia coli. Infect. Immun., 56: 2458-2466, 1988.

50. YEH, W.C.; YANG, R.-C. \& BOYLE, T. - Popgene version 1.31. Microsoft Windowsbased freeware for population genetic analysis. (http://www.ualberta.ca/ fyeh/), 1999.

51. ZARKO-POSTAWKA, M.; HUNDERUK, M.; MORDASKI, M. \& ZAKRZEWSKACZERWINSKA, J. - Organization and nucleotide sequence analysis of the ribosomal gene set (rrnB) from Streptomyces lividans. Gene, 185: 231-237, 1997.

52. ZHANG, L.; FOXMAN, B.; TALLMAN, P. et al. - Distribution of $d r b$ genes coding for Dr binding adhesins among uropathogenic and fecal Escherichia coli isolates and identification of new subtypes. Infect. Immun., 65: 2011-2018, 1997.

Received: 14 November 2000

Accepted: 17 September 2001 